\title{
Methods of developing critical thinking when working with educative texts
}

\section{Dana Cibáková}

\begin{abstract}
The present article focuses on the field of critical thinking, specifically on methods helping to stimulate critical thinking and understanding of a written text. The article also includes a practical illustration of how critical thinking is being cultivated with relation to developing skills of reading comprehension. This practical example presents a partial output of the research that focused on pupils in the second year of primary school, and it provides a suggestion how to use in practice methods developing critical thinking by means of reading comprehension.
\end{abstract}

Key words: critical thinking, methods developing critical thinking, reading comprehension, educational text, primary school pupil, lifelong learning.

\section{Introduction}

The incessant growth of ways to access information urges teachers (at primary and high schools as well as university lecturers instructing teachers through lifelong learning) to seek new options how to imbue students with critical and independent way of thinking. "To think in a critical manner involves capturing an idea and exploring its foundations, putting it through impartial criticism, comparing it with opposing views, 
making one's own assumptions and arriving through it at specific conclusions. Critical thinking is a difficult process of creative integration of thoughts and information, a process of concept restructuring" (Meredith, Steel, 2001, p. 29). Klooster (2002) defines critical thinking as an independent thinking where gathering information is just a beginning. According to him, critical thinking begins with asking questions, with posing problems that need to be solved. Petrasová $(2003$, p. 6) delimits the attributes of a critical thinker in the following manner: "(he/she is) curious, always formulating new questions, evaluating presumptions and arguments of the others (even if erroneous), searching for proofs and using them to make decisions, gaining new information and searching for new solutions."

It is thanks to the Orava Association that since 1997, critical thinking and its methods have been put into practice in the Czech Republic. This programme was founded by the Consorcium for Democratic Pedagogy members at the University of Northern lowa, Hobart and William Smith Colleges. Through this programme, teacher workshops are carried out that lead them to the following (Blažková, 2005):

- "methods are introduced through model classes where the participants go through the same experience as their students will; the model classes are subsequently analysed by the whole group;

- courses take into account possibilities of direct application of the presented methods into teachers' own practice - teachers plan to apply new methods in their own classes while the course is still running, using their own material and consulting their preparation both with each other and with the lectors;

- in between the individual parts of the course, the participants meet in smaller, regional groups to discuss which methods they used in their classes and with what result and they give each other advice;

- every next section of the course begins with a discussion concerning the results of the application of the hitherto presented methods; participants solve in group the most frequently occurring problems".

Courses are run in 4-5 modules lead by a team of lectors and consist of 80-100 classes in total. Another important part of the course is the concurrent applying of the described methods into the course participants' own practice. The programme authors prepared both for the lectors and the course participants 8 handbooks containing a description of the model classes and instructions how to analyse them; they also briefly tackle the pedagogical-psychological findings that have become the basis of active learning theory. The original texts used in the course are gradually being replaced by the tried and tested texts of domestic provenience (Blažková). 


\section{Methods developing critical thinking}

There is a variety of methods used to develop critical thinking. Among them are: Concept mapping, Cinquain, INSERT (Interactive Notating System for Effective Reading and Thinking) method, K-W-L (Know-Want-Learned) method, Cloze-test, Appeal-question stimuli aimed at different levels of reading comprehension, Venn diagram, PRAISE strategy, RISE strategy, REAP strategy, T-scheme, concept table, question-answer interchange, writing method "here and now", semantic element analysis, brainstorming, Concept-Text-Application method SQ3R (survey, question, read, recall, review) and others. The following section will be devoted to characterizing some of the methods mentioned. As our aim is not to characterize all methods of critical thinking, we will restrict ourselves only to those important to us mentioned in the practical example (see subchapter below).

\section{Concept mapping}

"A concept map is one of the means how to visually capture and express one's reading comprehension and mutual relations between the individual concepts and ideas" (Fisher, 1997, p. 8). "A concept map is a graphic representation reflecting pupil's knowledge structure of a specific curriculum. It is a visual representation of a specific curriculum" (Novak, Gowin, 1984, p. 57). A concept map captures concepts/information (graph nodes) and links between them - (connecting) lines through which it is possible to capture the relation between information, concepts, and alternatively also the succession of events or processes.

During the process of concept mapping, a scheme or a diagram is created in which concepts are arranged according to their mutual relations in such a manner students would benefit from it. Related concepts are linked together with lines and express a certain assertion (proposition). Relationships between concepts are expressed above the connecting lines, namely by brief rephrasing (Urbanová, Prokša, 2001).

\section{Venn diagram}

This diagram consists of two intersecting circles and represents the results of contrasting thoughts, concepts and themes while exploring their common and different features.

Method:

1. First, partially intersecting circles are drawn.

2. Before reading, in the course of reading or after the reading, main concepts are entered inside the circles.

3. Common features are assessed and entered into the common intersection area of the circles (Petrasová, 2003). 


\section{Appeal-question stimuli (term coined by Svobodová, 2000)}

Exercises are created in the form of pupil-oriented appeals and questions with the aim to probe the individual levels of reading comprehension: the ability to interpret and integrate information gleaned from the text, the ability to critically analyse and evaluate a given text (Liptáková et al., 2011).

\section{Cloze-test}

Cloze-test is a text consisting of approximately 250 words, while the first and the last sentence remain unchanged. The content of the text is not being adjusted, in contrast to its formal layout that contains empty slots that need to be filled in with appropriate words. Beginning with the second sentence, every n-th word is being left out. It is, for example, possible to leave out every fifth or eighth word, or every verb or noun can be systematically omitted from the text. "While making the cloze-test, it is possible to choose between the two methods. Either every $n$-th word is being omitted in a regular manner, i.e. an empty slot always appears after a certain fixed number of words, or words are being left out in accordance with a certain strategy (e.g. key concepts of the taught curriculum, nouns, verbs, etc.)" (Gavora, Šrajerová, 2009, p. 201). According to sense required, pupils must fill the gap with one word. Empty slots must appear after a fixed number of words otherwise different length would provide pupils with a clue as to which words need to be filled in. During the evaluation, even the synonymic equivalents of a given word are considered correct. In the process of omitting words, personal names or less-known words are usually not among those left out. For the needs of reading comprehension development, cloze-test represents a widely applicable method that can be modified to suit a particular aim, content or age.

The cloze-test evaluation is based on the number of correctly filled in words in relation to the overall number of words left out from the text. Words that the pupils have to fill in must make sense, and grammatical mistakes or deviations from the norm are not part of the evaluation (Gavora, Šrajerová, 2009). The cloze-test evaluation can be also approached from the point of view of previously stated criteria according to the degree of what we want to prove by a particular cloze-test.

In relation to critical thinking and its development via educational-instructional process, an EUR framework is known (Meredith, Steel, 2011). It involves a three-phase educational model whose individual phases are called Evocation, Comprehension and Reflection. In the evocation phase, a pupil actively remembers knowledge he or she has about a particular educational theme and is thus being prepared for the next activity. Evocation provides possibility to motivate a pupil and stimulate his/hers cognitive abilities. In the comprehension phase, pupils make themselves acquainted with new information and partake in activities crafted to enhance their ability to understand this information. Reflection offers the possibility to sort both the information known to 
pupils already prior to the educational activity and the knowledge they gained through the process of learning.

In the practical example that is part of the present article, this three-phase model is used for work with the provided educational text.

\subsection{Text understanding}

Drawing upon findings of text linguistics, text can be defined as "a relatively closed communicative unit which on the basis of content and illocutionary structure serves a propositional and pragmatic function" (Dolník \& Bajzíková, 1998, p. 10). In this sense we understand text as a structured object defined by a coherent succession of sentences. The attribute "communicative" expresses that the text is a unity based on but also mediating a communication activity. Every text enables further expansion of its information potential, that is, it is potentially open and that is why the text is being described as relatively closed. Propositional function means that text causes a recipient to construe a propositional complex in the sense of sender's intention. This function is followed by content structure of a text. The illocutionary text structure is motivated by pragmatic function, namely by text influencing certain speech acts (Dolník \& Bajzíková).

Text understanding is a hierarchical cognitive process, from with simple memory processing of information explicitly stated in a text through deducing textual connections to the integration and critical evaluation of gained information (Gavora, 1992).

The PIRLS study (Kramplová, 2012) delimits the individual levels of understanding in the following manner:

1. "The ability to identify information explicitly formulated in the text.

2. The ability to deduce information from the text (a reader deduces information and connections that the text does not formulate explicitly).

3. The ability to interpret and integrate information from the text (readers construe meaning beyond the text, relying on their previous knowledge and experience)

4. The ability to critically analyse and evaluate a certain text (readers analyse and evaluate a certain text from the point of view of its content, composition and language as well as its realised communicative intent; while doing so, they rely on the sum of their knowledge and experience and on the achieved level of language competence)". 
The term "text understanding" refers to the sum of intellectual abilities and skills and is divided into four subgroups that also exhibit a hierarchical form of organisation (Gavora, 1992, pp. 21-22).

a) Understanding applies only to the type of understanding that involves pupils knowing what is being communicated in the class and using it without the ability to relate it to other information or realizing its full implications.

b) Transfer means transformation (periphrasis, organisation) of information gained in the class without diminishing its truthfulness and accuracy. Under this category could be listed such examples as understanding an utterance with figurative meaning (metaphor, symbols, irony, hyperbole) or transfer of a mathematical proposition into a symbolic language and the other way around: the transfer from a symbolic language into a natural one.

c) Interpretation means elucidation of the taught curriculum. While in the previous subgroup of aims the original curriculum remained intact, interpretation involves reshaping of the taught information or presenting it from another point of view. In this category there could be listed, for example, understanding a certain text in its complexity on the required general level, the ability to interpret various types of entries concerning society and so on.

d) Extrapolation means broadening the original information through implications, detecting consequences, effects, etc, while these must be in accord with the conditions expressed in the original taught curriculum. This category contains, for example, making statements about a certain text with the help of deduction or the ability to predict future course of events.

Text understanding is essentially a psycholinguistic activity that involves three kinds of connection (Gavora, 1992, p. 23):

- connection between events from the objective reality and the textual elements describing these events

- connection between the individual textual elements (words, sentences, suprasentence structures)

- connection between textual elements and elements of a recipient's knowledge structure 


\subsection{Working with an educational text using methods developing critical thinking}

\section{EVOCATION}

Arrange letters in the exercise according to the given instructions (an exercise focused on the stimulation of cognitive functions - critical and logical thinking)

\section{1. Úloha}

Usporiadaj pismená $\mathbf{M}, \mathbf{S}, \mathbf{K}, \mathbf{B}, \mathbf{J}, \mathbf{T}$ do okienok tak, ako ti poviem:

a./ V okienkach 2,4 a 5 sú pismená $\mathbf{S}, \mathbf{T}$ a $\mathbf{M}$.

b. $/ \mathbf{M}, \mathbf{J}$ a B sú v okienkach 2,3 a 6 .

c. $/ \mathbf{J}$ je umiestnené $\mathrm{v}$ okienku za $\mathbf{M}$ a pred $\mathbf{S}$ :
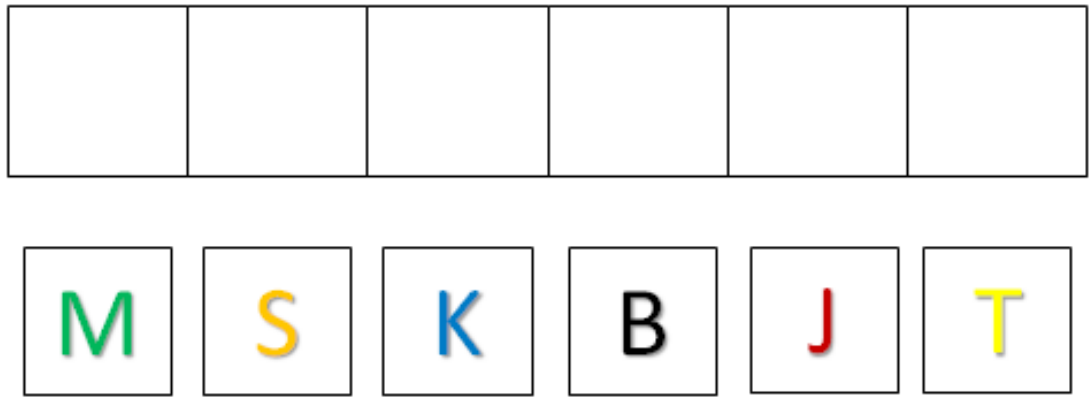

(Odpoved: K, M, J, S, T, B)

1. Exercise

Following my instructions, arrange letters $\mathrm{M}, \mathrm{S}, \mathrm{K}, \mathrm{B}, \mathrm{J}, \mathrm{T}$ into the squares below:

a) In the squares 2,4 and 5 are the letters $S, T$ and $M$.

b) $M, J$ and $B$ are in the squares 2,3 and 6 .

c) $J$ is placed in the square after $M$ and before $S$.

(Answer: $\mathrm{K}, \mathrm{M}, \mathrm{J}, \mathrm{S}, \mathrm{T}, \mathrm{B}$ )

Write down everything that comes to your mind when you hear the word "book": 
Figure 1

Concept map

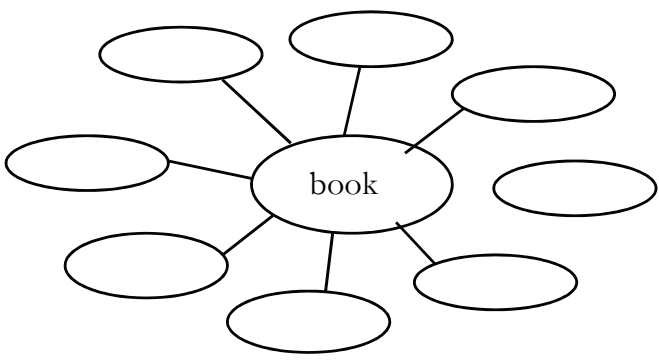

\section{READING COMPREHENSION}

Read carefully the following text about a book:

How do letters get into a book?

Letters were once typeset into a book manually. One by one and in a mirror image, a typesetter had to attach the letters of the whole one-page text into the print form. This form was then, by means of a printing press, copied several times as necessary. Today a page is prepared for print by using a computer. Books and magazines are usually printed by means of the so called offset method. Print desks with letters have the same flat surface everywhere but places containing letters have a surface differing from that in the empty spaces. That is the reason why they absorb paint that is subsequently transferred during the printing process onto the paper. Printing press was invented by Johannes Gutenberg. Printing press is one of the most important inventions that contributed to the progress and mental development of the European population. By the way, the first printed book was the famous Gutenberg Bible.

(Alischová, 2012, p. 145)

Appeal-question stimuli to evaluate levels of comprehension (Svobodová, 2000):

What is the name of the man who first invented printing press?

What was the name of the first printed book?

Explain how books had been made before the invention of the computer.

Explain the process of book-making in modern times.

What is the name of the method used for making books and magazines? 


\section{REFLECTION}

Name reasons why books are important for people.

Which types of books do you know?

What is your favourite book?

Try to explain the following concepts - author, writer, illustrator, publishing house.

Venn diagram - write in the circle what is characteristic for a writer and what for an illustrator. In the area where the circles intersect, write what they both can have in common.

Figure 2

Venn diagram

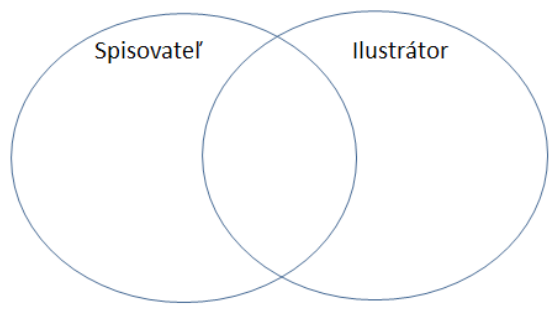

Writer Illustrator

\section{Cloze-test: How do letters get into a book?}

Letters were once typeset into a book manually. One by one and in a a typesetter had to attach the letters of the whole one-page into the print form. This form was then, by means of a press, copied several times as necessary. Today a page is prepared for print by using a . Books and magazines are usually printed by means of the so called method. Print desks with letters have the same surface everywhere but places containing letters have a surface differing from that in the empty spaces. That is the reason why they absorb that is subsequently transferred during the printing process onto the paper. Printing press was invented by Johannes . Printing press is one of the most important that contributed to the progress and mental development of the European population. By the way, the first printed book was the famous Gutenberg Bible. 


\section{Conclusion}

The aim of the present article was to acquaint with the concept of critical thinking and show some possibilities of its development by means of an educational-instructional process. We deemed necessary to characterize some of the methods used for developing critical thinking because they explain the working method through a practical example. The final practical illustration is a partial output of the qualitative research aimed at second-year pupils at St. Vorsila's primary school in Olomouc (Cibáková, 2015). The research output is the set of 18 stimulation units focused on the development of critical thinking by means of methods and exercises that can be used for learning from an informative text.

\section{References}

Alishová, T. (2012). Kde se bere tón v telefonu? Objasnění každodenních dětských záhad. Brno: Edika. Blažková, B. (2005). Čtením a psaním ke kritickému myšlení. Ikaros, 9, 11. (Dostupné na: http:// ikaros.cz/program-ctenim-a-psanim-ke-kritickemu-mysleni).

Cibáková, D. (2015). Possibilities and implementation of understanding development regarding objective texts among students of elementary school. Olomouc: UP. (in press).

Dolník, J. \& Bajzíková, E. (1998). Textová lingvistika. Bratislava: STIMUL - Centrum informatiky a vzdelávania FIF UK.

Gavora, P. (1992). Žiak a text. Bratislava: SPN.

Gavora, P., Šrajerová, H. (2009). Porozumenie textu zistované cloze-testom vo vztahu k niektorým charakteristikám. In Slovo o slove. Zborník Katedry komunikačnej a literárnej výchovy Pedagogickej fakulty Prešovskej univerzity. Prešov: Prešovská univerzita v Prešove, pp. 199-208.

Fisher, R. (1997). Učíme děti myslet a učit se. Praha: Portál.

Klooster, D. (2001). What is Critical Thinking? Thinking Classroom. A Journal of Reading, Writing and Critical Reflection, pp. 36-40. Retrieved from: http://media.wix.com/ugd/852b78_fe54bfa4eede 45d4b9ce0abec87c9430.pdf

Meredith, K. S., \& Steele, J. L. (2011). Classrooms of wonder and wisdom: Reading, writing, and critical thinking for the $21^{\text {st }}$ century. Thousand Oaks, Calif: Corwin Press.

Kramplová, I. a kol. (2012). Národní zpráva PIRLS 2011. Praha: Česká školní inspekce.

Liptáková, L'. a kol. (2011). Integrovaná didaktika slovenského jazyka a literatúry pre primárne vzdelávanie. Prešov: Prešovská univerzita v Prešove, Pedagogická fakulta.

Novak, J. D., \& Gowin, D. B. (1984). Learning how to learn. Cambridge: Cambridge University Press.

Petrasová, A. (2003). Práca s náučným textom na 1. stupni ZŠ. Prešov: Pedagogická fakulta Prešovskej univerzity.

Sampson, M. B., Rasinski, T. V., Sampson, M. R., \& Sampson, M. R. (2003). Total literacy: Reading, writing, and learning. Belmont, CA: Wadsworth/Thomson.

Svobodová, J. (2000). Jazyková specifika školské komunikace a výuka mateřštiny. Spisy Ostravské univerzity. Ostrava: Ostravská univerzita Ostrava, Pedagogická fakulta.

Urbanová, A., Prokša, M. (2001). Vedomostná štruktúra žiakov - jej zdroje a spôsoby zistovania. Technológia vzdelávania. IX., 8/2001, s. 4-7. 


\section{Acknowledgement}

This article is a partial output of the POST-UP II project - Support for building excellent research teams and intersectoral mobility at Palacky University in Olomouc II. No. 8100122667/12.

\section{Contact:}

Mgr. Dana Cibáková, Ph.D.

Faculty of Education

Palacký University in Olomouc

Žižkovo nám. 5

77140 Olomouc

E-mail: dana.cibakova@upol.cz 